\title{
Leader versus manager: Lessons from top business executives
}

\section{Chow Tong Wooi}

Business School, Malaysia University of Science and Technology, Selangor, Malaysia

jerrychow@must.edu.my

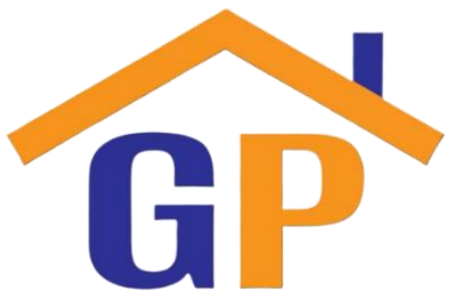

\begin{abstract}
Purpose: This article discusses the key differences between leadership and management. It also examines the business organizational executive's leadership styles of seven selected top executives: Donald Trump, Steve Jobs, Bill Gates, Mark Zuckerberg, Jeff Bezos, Jack Ma, and Tony Fernandez.
\end{abstract}

Research methodology: The methodological approach of the study focuses on the review of published literature postulating on the differences in the characteristics and functions of leadership and management.

\section{Article History}

Received on 13 June 2021

$1^{\text {st }}$ Revision on 24 June 2021

$2^{\text {nd }}$ Revision on 18 July 2021

Accepted on 30 July 2021
Results: Findings from the literature review indicate evidence that shows the differences and similarities between these two concepts of leaders and managers or leadership and management. The study also reveals that these top business executives demonstrated the contemporary leadership paradigms of transformational, charismatic, and servant leadership.

Limitations: One limitation is the review approach of the paper. The other is the analysis of leadership styles based on those top executives from the business sector.

Contributions: The article provides insights into the understanding of the evolvement of organizational management and the preferred leadership styles of top business executives. The findings on the leadership styles of the top business leaders add to the significance of the study.

Keywords: Leaders, Managers, Organizational management, Top business executives, Leadership styles

How to cite: Chow, T. W. (2020). Leader versus manager: Lessons from top business executives. Annals of Management and Organization Research, 2(1), 53-65.

\section{Introduction}

Many scholars and practitioners have equated leadership with management (Kanungo, 1998; Liphadzi, Aigbavboa, \& Thwala, 2017; Sirisetti, 2011). Literature review on leadership and management in the past has often theorized the concepts as the same (Edwards, Schedlitzki, Turnbull, Gill, 2015). These two terms, leadership and management, have frequently been used interchangeably. There have been debates about the differences between leadership and management. Some scholars do not see the need to differentiate between a leader and a manager. Nonetheless, there is a growing consensus among researchers concerning the need to distinguish between the concepts of leadership and management. A clear understanding of the differences and similarities between a manager and leader will expedite the appropriate development and practice (Day, 2001; Edwards et al., 2015). There are consequences in failing to distinguish the differences between these two concepts of management and leadership (Bertocci, 2009; House, 1995; Kotter, 2001). Hence, there is a need to rethink these two concepts for the effectiveness of organizational performance. 
The use of these two terms of leadership and management oftentimes overlap. Understanding the root word of these two concepts of management and leadership will enrich the understanding of both the terms and the meaning. The etymology of the word management is from the Latin term manus ('a hand'), which is involved in dealing with objects such as machines. On the other hand, the word leadership derives from the Anglo-Saxon word leader ('road' or 'path'), which carries the connotation of direction. Fundamentally, management deals with the complexity of the organizations, and leadership deals with change. The link between these two management and leadership concepts is under-research (Liphadzi et al., 2017). At the same time, though there are studies on the differences between the leader and manager, there is a lack of research on contemporary organizational business executives' leadership. This paper explores the various related perspectives and redefines the two concepts of the differences between a leader and manager in consideration of reviewing the top business executive's management experiences. The findings on the leadership styles of the top business leaders add to the significance of this study. The paper will contribute towards theory and practice in the field of leadership and management.

There are at least four reasons why the paper is written. First, leadership trends in the 21 st-century have evolved, particularly in the post-Covid-19 environment, to navigate these challenging times (Pretorius, Steyn, \& Bond-Barnard, 2018). Second, these changes influence the organizational leadership landscape (Bennett \& Lemoine, 2014; Mursal, Idaja, \& Dahie, 2016). Third, leadership practices need to reflect times' realities (Black, 2015; Marques, 2015). Fourth, distinguish the differences between leader and manager. As such, this will facilitate leadership development and practice (Black, 2015; Day, 2001; Liphadzi et al., 2017). In response, there is an urgency to relook at the associated concepts of the discussion in this paper and publish the findings.

\section{Methods}

This narrative review paper evaluates the related articles based on the keywords and combination of themes on leaders, managers, differences, leadership, and management and ideas emerging from the topic in the electronic databases written in English. The narrative review paper includes the process of evaluation, analysis, and synthesis of the trends emerging from the proposed topic. These data used were gathered from secondary data sources such as annual reports, journal articles, books, magazines articles etc, which were properly documented in the Reference section. The review also includes the cases of successful business executives in their field, focusing primarily on their leadership development and styles. These seven business executives, namely Donald Trump, Steve Jobs, Bill Gates, Mark Zuckerberg, Jeff Bezos, Jack Ma, and Tony Fernandez, were selected for the paper. The choice of these seven top executives was based on the purposeful sampling method with the selection criteria of choosing the proven top organizational business executives (Merriam \& Tisdell, 2016). These selected prominent business executives were recognized for their leadership and business accomplishments and achievements.

\section{Differences Between Management and Leadership}

There is substantial literature reviewing the difference between management and leadership roles (Ellis \& Abbot, 2015; Pretorius et al., 2018). There are claims that there are differences between leadership and management. Management authors have defined management as the process of achieving organizational objectives and goals effectively and efficiently through the core management functions of planning, organizing, leading or directing, and controlling (Robbins, Coulter, \& De Cenzo, 2017). Hence, management is about the progressive effort that aims at shaping an organization and contributing to its sustainability. As stated, management involves the elements of planning, organizing, directing, coordinating, and controlling. The definitions of management are traceable to Henri Fayol's classical writings in the 19th-century Industrial Revolution period. The vital essential areas of distinction are that management necessitates the framework of planning and budgeting, while leadership requires setting 
direction (Kotter, 2001; Northouse, 2015). Some core management activities include organizing, staffing, controlling, and problem-solving, whereas leadership requires aligning the motivation of people. The manager attains the goals through administrative activities of planning, budgeting, organization, and problem-solving. Hence, in reviewing these two concepts, leadership and management are both distinct and supportive actions. Each has its functions and distinctiveness (Kotter, $\underline{1990)}$.

Leadership is said to be a complex and multi-dimensional phenomenon (Ashkenas, Siegal, \& Spiegel, 2013; DePree, 1989). Scholars posit that leadership involved the influencing process in achieving the goal (Cole \& Kelly, 2011; Northouse, 2015). Similarly, it would be appropriate to consider Northouse's (2015) definition of leadership, where he states, "Leadership is a process whereby an individual influence a group of individuals to achieve a common goal" (p. 3). The leader's primary function in the organization is to do the right thing by providing direction, vision, set goals, and influencing followers. On the other hand, the manager ensures that the administration or process is right.

Many management scholars opined that leadership and management overlapped though the degree of overlapping is debatable (Avery, 2004; Pretorius et al., 2018). Some researchers contend that the concepts are complementary (Azad, Anderson Jr, Brooks, Garza, O’Neil, Stutz, \& Sobotka, 2017). Kotter (2001) stresses that leadership is different as compared to management, and the main differences between the two are that management deals with complex issues while leadership deals with change. He proposes that there is a distinguishing contrast between the two terms - leader and manager. Drucker (2007) highlights the differences between the two concepts of management and leadership, where he coins these often-quoted words, "Management is doing things right, leadership is doing the right things" (Edersheim \& Drucker, 2007, p. 21). Northouse (2015) writes that though there is a similarity between leadership and management, there are also well-defined differences between the two concepts. Kotter $\underline{(2001)}$ adds that "both leadership and management are necessary for success in an increasingly complex and volatile business environment" (p. 25). Studies have shown that an organization requires a combination of leadership and management for optimal effectiveness of organizational success (Robbins \& Judge, 2012; Sobocka-Szczapa, 2019). Some researchers have proposed that an ideal organization should opt to have a balance of leaders and managers (Pretorius et al., 2018; Toor \& Ofori, 2008; Toor, 2011).

Leadership in the 21 st-century has evolved (O’Connell, 2014; Petrie, 2014; Van Wart, 2013). The winds of change buffeting the 21 st-century global landscape in many spheres, particularly with the recent Covid-19 pandemic, further complicate the environment. These factors contributed to the paradigm shift in the leadership of organizations. Hence, leaders are required to think differently. Management executives need to shift from operating from old paradigms management mindset, which are based on the bureaucratic framework of the industrial age. Old traditional thinking and archaic leadership practices will not develop growth in a complex business environment (Ashkenas et al., 2013; Bennett \& Lemoine, 2014). Management approaches tend to emphasize stability, while leadership approaches value relationship, empowerment, and change. The new paradigm is changing the requirements of manager-ship, and managers need to become influential leaders. In table 1, Kotter (1990) shows the differences in the functions of management and practices.

Table 1. Functions of Management and Leadership

\begin{tabular}{|l|l|}
\hline Management & Leadership \\
Produces Order and Consistency & Produces Change and Movement \\
\hline Planning and Budgeting & Establish Direction \\
$\bullet \quad$ Establish agendas & $\bullet \quad$ Create a vision \\
- Set timetables & - Clarify the big picture \\
\hline
\end{tabular}




\begin{tabular}{|l|l|}
\hline - Allocate resources & $\bullet$ Set strategies \\
\hline Organizing and Staffing & Aligning People \\
- Provide structure & $\bullet \quad$ Communicate goals \\
- Make job placements & - Seek commitment \\
- Establish rules and procedures & - Build teams and coalitions \\
\hline Controlling and Problem-solving & Motivating and Inspiring \\
- Develop incentives & $-\quad$ Inspire and energies \\
- Generate creative solutions & - Empower subordinates \\
$-\quad$ Take corrective action & - Satisfy unmet needs \\
\hline
\end{tabular}

Source: Adapted from a Force for Change: How Leadership Differs from Management by Kotter, 1990

\section{Examining the Roles of Leaders and Managers}

There are scholars that have suggested that some leaders are competent managers, while some managers are impressive leaders (Armandi, Oppedisano, \& Sherman, 2003; Cole \& Kelly, 2011). Conversely, it may not be true that a leader has managerial abilities, and a manager has leadership capabilities. Regardless, both strong leaders and capable managers are needed for organizations to survive and thrive (Azad et al., 2017; Robbins \& Judge, 2012; Sobocka-Szczapa, 2019; Tran, 2021). Literature shows that there are distinguishing characteristics and differences between the concepts of managers and leaders (Boyett \& Boyett, 1998; Bertocci, 2009). As alluded to, leaders are required to create visions and inspire organizational members to achieve goals, while managers are needed to plan, organize efficiency, and oversee the day-to-day operations. It is interesting to note that Spicker (2012) has proposed that a leader should have leadership abilities and management skills as well. Likewise, other management scholars concur that in today's complex organization, it is crucial to have individuals who can manage and lead effectively (Denning, 2011; Sobocka-Szczapa, 2019). Furthermore, some researchers highlight that organizations need to develop leaders-managers who can adapt to such a role (Azad et al., 2017; Bolden, 2004). Some scholars propose the combination of leadership and management in their organizational practice (Goold \& Campbell, 1987; Nguyen \& Hansen, 2016). Pisapia (2009) highlighted that the strategic leadership approach combined both the management and leadership concepts.

As discussed, leadership and management are both different yet, at the same time, related functions. A progressive organization may consider incorporating both the development and practice of leaders and managers in organizational management. There are suggestions that such an integrative approach would contribute towards sustainable organizational growth and long-term competitive advantage. Table 2 lists the study on the comparison of these two concepts of leaders and managers by Kozak (1998) (As cited in Bertocci, 2009).

Table 2. A Comparison of Leaders and Managers

\begin{tabular}{|l|l|}
\hline Leaders & Managers \\
\hline Goal-oriented & Task-oriented \\
\hline Inspires / Empowers & Directs \\
\hline Thoughtful & Industrious \\
\hline Results-oriented & Action-oriented \\
\hline Effective & Efficient \\
\hline Long-term planner & Short-term planner \\
\hline Policy-oriented & Implementation oriented \\
\hline Mission-oriented & Program oriented \\
\hline Attracts talent & Recruits talent \\
\hline Works in the future & Works in present \\
\hline Studies the environment & Observes operations \\
\hline National / International perspective & Agency perspective \\
\hline Process-oriented & Product-oriented \\
\hline Consults & Consulted \\
\hline
\end{tabular}




\begin{tabular}{|l|l|}
\hline Decides & Recommends \\
\hline Utilizes staff work & Provides staff work \\
\hline Mediates & Champions \\
\hline Focuses on concepts & Focuses on details \\
\hline Looks outward & Looks inward \\
\hline Represents entire institution / unit/ agency & Represents separate organizational functions \\
\hline Sees the whole & Sees parts of the whole \\
\hline Operates in internal and external politics & Operates in internal politics \\
\hline Delegates & Oversees \\
\hline
\end{tabular}

Source: Adapted from Leadership in Organizations by Bertocci, 2009

The assertion that organizations, in general, are over-managed and under-led is particularly true when the study of leadership as a discipline and practice is relatively young in some parts of the world in comparison to other parts of the developed world. This is due to the imbalanced practices of leadership and management over time. It would appear that both strong leaders and managers are needed for organizations to survive and thrive.

The historical development of the nation is also a major contributing factor to the inclination towards the organizational practices of leading either by management or leadership. Besides, Zaleznik (1977), in his classic award-winning article, claimed that the educational process and the bureaucratic setup of organizations tend to breed managers. He has asserted that leaders are rare breeds (As cited in Georgiades \& Macdonell, 1998). Scholars have warned that there are consequences to the neglect of academic literature in the failure to distinguish the differences between leadership and management (Gerard, Mcmillan, \& D'Annunzio-Green, 2017; Hall \& Rowland, 2016; House, 1995). The primary reason for their argument is that there was and still, is a dire need for leadership in many spheres of societies (Hall \& Rowland, 2016; House, 1995; Kotter, 2001).

There is evidence which indicates that context influences leadership development and practice. The contextual organizational management factors influence outcomes and practices. The historical development of a nation is also a major contributing factor as to the inclination towards the organizational practices of leading either by management or leadership. For example, research has shown that Malaysian managerial practices are traceable to the British colonial legacy (Arham, 2014). The top-down management style resulted in the practice of the autocratic style over time. Management leaders then were exposed to such leadership styles, which may have worked during that period. Arguably, it can be concluded that Malaysian organizations are still being dominated by managerial practices instead of leadership. Also, leadership scholars have implied that the bureaucratic arrangements of organizations tend to produce managers (Zaleznik, 1977).

\section{Highlights of the Selected Top Business Executives}

There are managerial and leadership ideas that we can learn from the contemporary business organizational executives of today. A substantial number of organizational leadership studies in the past have focused on political leaders such as Abraham Lincoln, Winston Churchill, and Nelson Mandela. Despite learning from political leadership, there are also leadership lessons that one can discover from the executives of business organizations. The paper highlights seven contemporary top business organizational executives, namely, Donald Trump, Steve Jobs, Bill Gates, Mark Zuckerberg, Jeff Bezos, Jack Ma, and Tony Fernandez.

Research studies have linked these top contemporary business executives to recent contemporary leadership theories. Although their personality and styles differ, they have exhibited their talent and achieved their leadership and organizational goals. Undeniably their managerial and leadership practices have contributed to the advancement of their organizations. Though this article focuses on 
each of their predominant leadership styles based on studies by researchers, they were likely exposed to vast administrative, technical, managerial, and leadership styles and trends in their early formative years. Based on the overview of the seven top business organizational executives' management and leadership approaches, four demonstrated evidence of transformational leadership, two charismatic leaderships, and one servant leadership. It needs to be noted that this research was conceptualized prior to the outbreak of the Covid-19 pandemic. Certainly, the Covid-19 pandemic has an impact on the global leadership landscape, affecting the financial and economic performances of organizations and countries.

\section{a) Donald Trump}

Donald Trump was the past $45^{\text {th }}$ President of the United States. He entered the United States presidential election and got elected into office in 2016. However, his career started as a businessperson in the real estate industry. His company, which he named The Trump Organization, was involved in building and renovating skyscrapers, hotels, casinos, and golf courses. Immelman (2017), in his study on the leadership style of U.S. President Donald Trump, posits that Trump's prevailing temperament traits are described as ambitious/exploitative, outgoing/impulsive, and dominant/controlling pattern. However, his overall leadership style has evolved into a distinctive, charismatic leadership. Charismatic leaders developed a certain quality and giftedness or abilities that set them apart from ordinary people (Robbins \& Judge, 2012; Northouse, 2015). The research authors described Trump's predominant personality traits as ambitious, outgoing, with a feature of being dominant (Immelman, 2017). The other leadership style ascribed to Trump regarding his approach based on the leadership models developed by Herman and Preston (1995) and Kaarbo (1997) in Immelman, 2017) is motivation, goal-oriented, performance, managerial, and executive style.

\section{b) Steve Jobs}

Steve Jobs catapulted into the business arena when he started Apple Incorporated with Steve Wozniak, a multinational technology company in California, United States. Jobs got recognized as a business magnate, industrial designer, investor, and media proprietor. He has served as the chairman, chief executive officer, and majority shareholder. During job's formative years, he has shown aptitudes and skills for administration, technical, and creativity (Silva, 2014). The job was known to drive excellence, modesty, and elegance, and he ensured that employees who worked at Apple are reminded. He regularly insisted his employees think out of the box and initiate products that are innovative. The company eventually was brought to unprecedented heights, as evident by a report that stated, at the end of 2019, Apple's global market share was 20\%, capturing the top position globally. (Apple has recorded an impressive performance in Q4 2019 Worldwide Smartphone Market, while Huawei achieves the number two globally for 2019, 2020).

Though Jobs has fulfilled some critical roles in the top organizational management, he appeared to exhibit transformational leadership (Toma \& Marinescu, 2013). The essence of transformational leadership is about the effect of change and transformation on people and the organization (Burns, 1978; Gidens, 2017; Ramsay, Rutti, Lorentz, Barakat, \& Sant'anna, 2017). As evident through his transformational leadership approaches, he motivates others to rise above their self-regard, contributing as proactive team members and influence organizational members to become leaders. He was credited as a modern leader, visionary, perfectionist, innovative, and complex (Sen \& Eren, 2012; Silva, 2014). He was described as a successful leader in a competitive industry. Also, during his leadership role, he has displayed strategic leadership in his decision-making in market share positioning and product services (Sosik, Jung, Berson, Dionne, \& Jaussi, 2005). Due to the job's multi-facet capabilities, he got credited for belonging to the pantheon of America's great modern leaders (Toma \& Marinescu. 2013). 


\section{c) Bill Gates}

Bill Gates, born in 1955 in Seattle, Washington, United States, is recognized as an outstanding entrepreneur and business leader of modern times. He is a well-known technologist and entrepreneur of the micro-computer period in the 1970s and 1980s. The software program was written by him while at prep school at the age of 13. During Gates' early years, he has shown interest in computer programming (Silva, 2014). He later launched Microsoft with his friend, Paul Allen. Since then, he has served in the various positions of chairman, President, chief executive officer, chief software architect, and shareholder.

Like Steve Jobs, in his early days, he has developed the ability to envision, administrative aptitude, technical skills, innovation, and intelligence (Silva, 2014). Even from a young age, he has shown talent in administrative and technical skills, vision for a business, and creativity (Silva, 2014). Gates' leadership strategy and principles become described as parallel to the servant leadership paradigm (Zenter, 2016). Servant leadership teachings are a concern for people by helping them personally and professionally instead of one's interest (Northouse, 2015; Parris \& Peachey, 2013; Spears, 2002). Bill Gates exhibited these principles of servant leadership through his non-profit Gates Foundation. His philanthropy and humanitarian work have been an inspiration to others.

\section{d) Mark Zuckerburg}

Mark Zuckerburg initiated Facebook and has remained as the Chief Executive Officer of the company. He also co-founded the solar sail spacecraft project named Breakthrough Starshot. In his early years in high school, he had excelled in classes. He had won prizes in physics, mathematics, astronomy, and classical studies. During his college days, he could read and write Hebrew, Latin, ancient Greek, and French. Zuckerburg is a successful leader that established an organization that paved a new way of communication to billions of people globally (Baldonado, 2015). Facebook is an example of his vision of connecting the world's people. According to statistics, Facebook users have grown exponentially to one billion in 2012.

Zuckerburg possessed many leadership traits that were analyzed by personality researchers. In his early years, while enrolled at Harvard University, he showed interest in programming and technology. He has continued to develop as a Web developer and was known as a reputable software developer. His leadership approaches got linked to transformational leadership (Baldonada, 2015; Ramsay et al., 2017). He is said to depict the leadership style of encouraging and aggressive at the same time. He continually demands innovation and growth. The results of his leadership have contributed towards areas such as innovation, customer growth, employee satisfaction, organizational value, and market share in the organization that he is involved in (Mullins, 2010). TIME magazine in 2012 named Zuckerburg as one of the 100 wealthiest and influential personalities.

\section{e) Jeff Bezos}

Jeff Bezos founded Amazon, an e-commerce company, and later became the Chief Executive Officer. $\mathrm{He}$ had his early education with Princeton University in electrical engineering and computer science. Before starting the e-commerce business, Wall Street provided him with opportunities to work in a variety of fields. Along with his career, he has managed many other investments through his capital investment firm, Bezos Expeditions. Throughout his career, he had vast experience in the trade, banking, and management. While establishing Amazon, he has developed and fine-tuned his management and leadership skills.

De Andres (2017), a finance executive, wrote that Bezos was equipped with the right knowledge and experience and was able to make change happen inside the organization. He exemplifies the characteristics of a transformational leader (Marques, 2015; Ramsay et al., 2017). De Andres (2017) states, "We can also see that transformational leaders are also those who understand the importance of 
placing themselves, their organization, the society, and the world, first before profits" (para. 6). Additionally, De Andrés (2017) shares the seven principles of transformational leadership demonstrated by Bezos: i) Simplification: When articulating the direction of the team he is leading, Bezos uses clear and practical language. ii) Motivation: In Amazon, Bezos understands the employees' likes and dislikes, which in turn, knowing what motivates them and vice versa. By doing this, Bezos and Amazon gain the support and consensus to promote team vision. iii) Determination: Bezos always insists on the highest standards, especially when he talks about the determination to complete the race in spite of the challenges that they faced. iv) Mobilization: Bezos believes in assembling the right people to get the work accomplished by entrusting and providing the right team. v) Preparation: In Amazon, Bezos drives those who worked for him to be perpetual learners. vi) Facilitation: Bezos recognizes this value of developing its employees' abilities. vii) Innovation: Change in the organizational environment is unavoidable. Bezos recognizes the need for improvement and encourages it accordingly.

As apparent, Bezos manages a disruptive firm, uses organizational change to espouse commitment, which shows compelling narratives about the direction, and promotes a road map before unplanned issues arise. Transformational leaders motivate people to focus on vision and the job at hand. In times when organizations face turbulence or great challenges, organizations need to move fast, and their managers should not depend wholly on the organizational structure to manage business activities. It is in these settings that transformational leaders can inspire team members to be engaged, to develop values and reach the goals of the organization, and advance with persistence.

\section{f) Jack Ma}

Like most successful entrepreneurs, Jack Ma became described as an entrepreneur with many capabilities. He initially started as an English teacher but later ventured into business. In his interviews with the journalists, he frequently talked about many job applications in his early years but was rejected. He applied for 30 jobs but was rejected by all. In early 1990, Ma learned about the internet business and started his company. He also ventured into other related information technology ventures. Ma is the first entrepreneur to develop e-commerce into an online giant, Alibaba, in China. The firm he founded is worth over $\$ 400$ billion. His accomplishment in the business world was recognized and he has subsequently won many awards and honors.

Researchers postulate that Ma's organizational management approach progressively evolves according to the requirements of the environment (Tham \& Yazdanifard, 2015). Write-ups on Ma's experiences seem to indicate that Ma's management of Alibaba's operation evolved from the autocratic to a conductive, persuasive, and democratic style of management (Tham \& Yazdanifard, 2015). When he started the business, one of his friends, Zhang Yin, described Ma as having the capacity to do things other men could not (Rana, 2014). Ma is considered a charismatic visionary leader (Khzam, 2015; Northouse, 2015). He is said to be a strategic leader as well. He is the first businessman to initiate ecommerce and started the first internet merchandising website in China. Charismatic leaders can develop and articulate their vision and take risks to achieve their vision. There are some similarities between charismatic and transformational leadership. Charismatic leadership is an extension of transformational leadership (Pawar, 2016).

\section{g) Tony Fernandez}

Tony Fernandez has his early training in accountancy from the United Kingdom schools. He did his early education at Epsom College, followed by the London School of Economics, and completed his study in accounting. Initially, his work life was briefly with Virgin Atlantic as an auditor. Subsequently, he assumed the position of financial controller of the Virgin Communication group in England. He was later attached to Warner Music International, London, as Financial Analysis. Also, he took the responsibility as the Chief Executive Officer of Warner Music Records (Malaysia) before venturing into setting up Tune Air Sdn. Bhd. Fernandez then introduced the first budget basic essential airline, 
Air Asia. His other main ventures included starting the no-frills concept hotel, Tune Hotels founded the Caterham Formula One team, and being involved in the English football club teams.

The name Tony Fernandez is synonymous with Air Asia, which has grown into a world-famous lowcost airline that operates both domestically and internationally. It is now the largest low-cost airline in Asia. The achievement of Air Asia is attributable to the leadership of Tony Fernandez and his partners. During his work, Fernandez has demonstrated foresight and vision by turning Air Asia into a wellknown brand. There was evidence of healthy leadership practices in managing a growing airline like Air Asia. Researchers in studying the leadership traits of Fernandez have attributed the charismatic leadership traits to him (Kuppusamy, n. d). At the same time, Fernandez uses transformational leadership approaches as analyzed from his interview statements (Gidens, 2017; Kamisan \& King, 2013; Ramsay et al., 2017). He has described the various aspects of the dimensions of the transformation of idealized influence, intellectual stimulation, individualized influence, and inspirational motivation. Transformational leadership comprises four core inter-related dimensions. One of the sub-domains of transformational leadership is charismatic traits.

The key discovery of the organizational management practices of the seven top business executives has evolved towards transformational, charismatic, and servant leadership. These top business executives are successful business people who have rich organizational experiences and resources. Apart from their education, most of them have started their firms or companies and have vast experience in organizational management and leadership. They have built, grown, and established their companies and businesses. At the same time, they have their workforce, management teams, and consultants. Thus, they certainly would have hands-on experience in the techniques of effective organizational leadership and management. More significantly, there was evolvement, development, adaptation, and adoption of their leadership practices in their search for excellence, as evident in the findings. Table 3 shows the outcomes of the leadership approaches of the seven top business organizational executives.

Table 3. Leadership Approaches of Seven Top Business Organizational Executives

\begin{tabular}{|l|c|c|c|}
\hline Top Executives & $\begin{array}{l}\text { Transformational } \\
\text { Leadership }\end{array}$ & $\begin{array}{l}\text { Charismatic } \\
\text { Leadership }\end{array}$ & Servant Leadership \\
\hline Donald Trump & & $\sqrt{ }$ & \\
\hline Steve Jobs & $\sqrt{ }$ & & $\sqrt{ }$ \\
\hline Bill Gates & $\sqrt{ }$ & & \\
\hline Mark Zuckerberg & $\sqrt{ }$ & $\sqrt{ }$ & \\
\hline Jeff Bezos & $\sqrt{ }$ & & \\
\hline Jack Ma & $\sqrt{ }$ & & \\
\hline Tony Fernandez & & & \\
\hline
\end{tabular}

Source: Author's Literature Review, 2021

\section{Conclusion and Implications}

This article began by discussing the theme of the leader versus a manager. Researchers stressed the need to explicitly clarify the concepts of leadership and management in research (Edwards et al., 2015). The clarification will help reduce the ambiguities and confusion between the two constructs of leaders and managers. Illuminating the differences between leaders and managers will facilitate leadership development and practice (Black, 2015; Day, 2001; Liphadzi et al., 2017). A clear understanding of the distinction between leaders and managers will promote leadership development or develop the leadership competencies of individuals accordingly. The old paradigm of traditional management may have worked in the past, but the new paradigm demands that managers administer as leaders. So, the shift in focus from the management paradigm to the leadership approach would also result in the style of leadership. 
In today's changing dynamic information era and challenging times, the management needs leaders to cope with unexpected demands and establish the sustainability of the operation. At the same time lead the enterprise to achieve a competitive edge in the marketplace. Organizations also need managers to maintain a smoothly functioning workplace and to utilize resources effectively. Notwithstanding, researchers are suggesting more leaders in the context of the challenging times of the evolving 21 stcentury organizational landscape. There is also the recognition for the roles of leaders-managers who can lead and adapt at the same time. In addition, there are calls for the organizational balance of management to include influential leaders and managers to achieve optimal success in performance.

The paper then reviews seven top business executives and the evolvement of their leadership journey. The findings of the leadership approaches of the top seven top business executives are in line with the teachings of contemporary leadership theories. The leadership styles of these business executives have contributed to modern business organizational leadership and management. The evidence of the leadership practices of these top business leaders affirms that leadership is a multi-facet concept that has many dimensions (Chow \& Adedeji, 2020; Goldman, Schlumpf, \& Scott, 2017). Organizations at large are to recognize the need to develop and raise more leaders for 21st-century leadership and management (Toor \& Ofori, 2008; Smet, Lurie, \& St George, 2018).

In summation, these are the themes that emerged from the review of the study. There are significant differences between a leader and a manager. The research findings indicate that the leadership approaches of the seven top business organizational executives reflect the contemporary leadership paradigms, which are in tandem with the times. As evidenced by the seven top organizational executives, these relevant leadership practices have proven to contribute towards organizational leadership and performance. Undeniably, there are other success factors involved in organizational performance. It needs to be emphasized that leaders are not only needed in business entities but in every sphere of society (Gerard et al., 2017; Hall \& Rowland, 2016; House, 1995; Zeti, 2014). Similarly, Zaleznik (1977) asserts that leaders are a rare breed required in leadership work, grouping, and society. Some researchers opined that an ideal organization combines both the leadership and managerial competencies in the organization (Goold \& Campbell, 1987; Toor, 2011; Sobocka-Szczapa, 2019; Tran, 2021). Generally, organizations require a new generation of leaders to thrive in the context of the 21 st-century evolving landscape (Bennis, 1989; Iordanoglou, 2018). As reiterated in literature, organizations of the 21st-century need more leaders (O'Connell, 2014; Sirisetti, 2011). Leaders who will develop the related competencies capable of responding to the 21 st-century demands, challenges, and opportunities.

In today's competitive world, most entities need capable leadership that will improve their performance (Manning \& Curtis, 2019; O'Connell, 2014; Pisapia, 2009). Therefore, it is important to apply the appropriate concept of leadership in tandem with the times as the key to competitive advantage for progressive leadership development and practice. Those in organizational management need to decide on developing leadership approaches relevant to the times for practice. There should be more educational leadership courses offered for leadership enrichment and enhancements. Further study is needed in this area of discussion on the role of the leader and manager for 21 st-century organizations at the different management levels, sectors, and fields.

\section{References}

Arham, A. (2014). The relationship between leadership behavior, entrepreneurial orientation and organizational performance in Malaysian small and medium enterprises. (Unpublished doctoral dissertation). Retrieved from http://researchbank.rmit.edu.au/view/rmit: 160765

Armandi, B., Oppedisano, J., \& Sherman, H. (2003). Leadership theory and practice: a "case" in point. Management Decision, 41 (10), 1076-1088.

Ashkenas, R., Siegal, W., \& Spiegel, M. (2013). Mastering organizational complexity: A core competence for 21 st-century leaders. Research in Organizational Change and Development, 21, 29-58. 
Avery, G. C. (2004). Understanding leadership: Paradigms and cases. Thousand Oaks, CA: Sage Publications.

Azad, Anderson Jr, Brooks, Garza, O’Neil, Stutz, \& Sobotka. (2017). Leadership and management are one and the Ssme. American Journal of Pharmaceutical Education 2017; 81 (6) Article 102.

Baldonado, A. M. (2015). What can we learn from young business leaders today? International Journal of Managerial Studies and Research. Vol, 3, Issue 6, pp. 40-43. ISSN 2349-0349. pp. 40-43.

Bennett, N., \& Lemoine, G. J. (2014). What a difference a word makes: Understanding threats to performance in a VUCA world. Business Horizons, 57 (3), 311-317.

Bennis, W. G. (1989). Managing the dream: Leadership in the 21 st-century. Journal of Organizational Change, $2,7$.

Bertocci, D. I. (2009). Leadership in Organizations. University Press of America, Maryland, U.S.

Black, S. A. (2015). Qualities of effective leadership in higher education. Open Journal of Leadership, $4(02), 54$.

Bolden, R. (2004). What is Leadership? Centre for Leadership Studies, University of Exeter. Retrieved May 20th, 2020, from business school.exeter.ac.uk/documents/.../what_is_leadership.pdf.

Boyett, J. H., \& Boyett, J. T. (1998). The guru guide: The best ideas of the top management thinkers. New York, NY: John Wiley \& Sons Inc.

Burns, J. M. (1978). Leadership. New York. NY: Harper and Row Publishers.

Chow, T. W., \& Adedeji, B. S. (2020). Multi-facet leadership approach for organizational performance in the evolving globalized landscape of the new millennium era. International Journal of Psychosocial Rehabilitation, Vol. 24, Issue 02, 2020 ISSN: 1475-7192

Cole, G. A., \& Kelly, P. (2011). Management theory and practice $\left(7^{\text {th }} E d\right)$. Hamshire, U.K.: SouthWestern Cengage Learning.

Day, D. V. (2001). "Leadership development: A review in context." The Leadership Quarterly, 11 (4), 581-613.

De Andrés, F., 2017. Jeff Bezos: The Best Living Transformational Leader as Example. Online. Retrieved May $11^{\text {th }}$, 2020 from https://www.linkedin.com/pulse/jeff-bezos -best-living-transformational-leader-f\%C3\%A9lix-deandr\%C3\% A9s

Denning, S. (2011). The reinvention of management. Strategy \& Leadership, Vol. 39, No. 2: pp. 9-17.

DePree, M. (1989). Leadership is an art. New York: Bantam Doubleday Dell Publishing Group.

Drucker, P. F. (2007). Management challenges for the 21st-century. New York, NY: Harper Collins Publishers.

Edersheim, E.H. \& Drucker, P.F. (2007). The definitive Drucker: Challenges for tomorrow's executives, New York, NY: McGraw-Hill Professional.

Edwards, G., Schedlitzki, D., Turnbull, S., \& Gill, R. (2015). Exploring power assumptions in the leadership and management debate. Leadership \& Organization Development Journal. Vol. 36 No. 3, 2015. pp. 328-343.

Ellis, P., \& Abbot, J. (2015). Exploring the differences between leaders and managers. Journal of Renal Nursing. Vol. 7. No. 2. 2015.

Georgiades, N., \& Macdonell, R. (1998). Leadership for competitive advantage. West Sussex, UK: John Wiley \& Sons Ltd.

Gerard, L., Mcmillan, J., \& D’Annunzio-Green, N. (2017). Conceptualizing sustainable leadership. Industrial and Commercial Training. Vol. 49, Issue 3. pp. 116-126, https://doi.org/10.1108/ICT$\underline{12-2016-0079}$

Giddens, J. (2017). Transformational leadership: What every nursing dean should know. Journal of Professional Nursing. https://doi.org/10.1016/j.profnurs.2017.10.004

Goldman, E. F., Schlumpf, K. S., \& Scott, A. R. (2017). Combining practice and theory to access strategic thinking. Journal of Strategy and Management. Vol. 10. Issue 4. Pp. 488-504. https://doi.org/10.1108/JSMA-02-2017-0012

Goold, M., \& Campbell, A. (1987). Many best ways to make strategy. Harvard Business Review, 65 (6), 70-76. 
Hall, R. D., \& Rowland, C. A. (2016). Leadership development for managers in turbulent times. Journal of Management Development. Vol. 35. Issue 8. pp. 942-955. https://doi.org./101108/JMD-092015-0121

House, J. (1995), leadership in the twenty-first century: a speculative inquiry, in Howard, A. (Ed.), The Changing Nature of work, San Francisco, CA: Jossey-Bass Publishers.

Immelman, A. (2017). The leadership style of U.S. president Donald Trump. (Working Paper No. 1.2). Collegeville and St. Joseph, MN: St. John's University and the College of St. Benedict, Unit for the Study of Personality in Politics. Retrieved May 11th, 2020 from Digital Commons website: http://digitalcommons.csbsju.edu/psychology_pubs/107/

Iordanoglou, D. (2018). Future trends in leadership development development practices and the crucial leadership skills. Journal of Leadership, Accountability and Ethics. Vol. 15 (2).

Kanongo, R. N. (1998). Leadership in organizations: Looking ahead to the 21 st-century. Canadian Pschology/Psychologie Canadienne, 39 (1-2), 71.

Kamisan, A., King, E. M. Transactional and transformational Leadership: A comparative study of the difference between Tony Fernandez (Airasia) and Idris Jala (Malaysia Airlines) leadership styles from 2005-2009. International Journal of Business and Management, Vol. 8, No. 24. ISSN 18333850. pp. 107-116.

Khzam, M. A. (2015). Leadership and change management. Retrieved March, $3^{\text {rd }} 2020$ from www.academia.edu > Leadership_And_Change_Manage.

Kotter, J. P. (1990). A Force for change: How leadership differs from management. New York, NY: Free Press.

Kotter, J. P. (2001). What leaders really do? Boston, MA: Harvard Business Review.

Kuppusamy, S. K. (n. d). Leadership and the management of change: Air Asia Berhad. Online. Retrieved June $1^{\text {st }}, 2020$ from www.academis.edu.

Liphadzi, M., Aigbavboa, C. O., \& Thwala, W. D. (2017). A theoretical perspective on the difference between leadership and management. Procedia Engineering. 196. pp 478482. Doi: 10.1016/j.proeng.2017.07.227

Manning, G, \& Curtis, K. (2019). The Art of Leadership. 6th edition. New York, NY: McGraw-Hill.

Marques, J. (2015). The changed leadership landscape: what matters today? Journal of Management Development, 34 (10), 1310-1322.

Merriam, S. B., \& Tisdell, E. J. (2016). Qualitative research ( $4^{\text {th }}$ Ed). San Francisco, CA: Jossey-Bass.

Mullins, I. J. (2010). Management and organizational behaviour, $9^{\text {th }}$ edition, Edinburg: Pearson Education Limited.

Mursal, H. M. A., Idaja, M. M. O., \& Dahie, A. M. (2016). The Impact of globalization on higher education: Empirical survey from universities in Mogadishu-Somalia. International Journal, 4(9).

Nguyen, N. and Hansen, J.Ø. (2016), "Becoming a leader-manager: a matter of training and education", Development and Learning in Organizations, Vol. 30 No. 6, pp. 10-12. https://doi.org/10.1108/DLO-07-2016-0056

Northouse, P. G., (Ed.). (2015). Leadership: Theory and practice. Thousand Oaks, CA: Sage publications.

O'Connell, P. K. (2014). A simplified framework for 21 st-century leader development. The Leadership Quarterly. 25(2), 183-203, doi:10.1016/j.leaqua.2013.06.001

Parris, D. L., \& Peachey, J. W. (2013). A systematic literature review of servant leadership theory in organizational contexts. Journal of business ethics, 113 (3), 377-393.

Pawar, A., (2016). Transformational leadership: inspirational, intellectual and motivational stimulation in business. International Journal of Enhanced Research in Management \& Computer Applications. ISSN: 2319-7471, Vol. 5, 2016.

Petrie, N. (2014). Future trends in leadership development. Retrieved November18th, 2015 from www.ccl.org/leadership/pdf/research/futuretrends.pdf

Pisapia, J. (2009). The strategic leader: New tactics for a globalizing world. Charlotte, NC: Information Age Publishing. 
Pretorius, S., Steyn, H., \& Bond-Barnard, T. J., (2018). Leadership Styles in Projects: Current Trends And Future Opportunities. South African Journal of Industrial Engineering November 2018 Vol 29(3) Special Edition, pp 161-172.

Ramsay, J. R., Rutti, R. M., Lorentz, M. P., Barakat, L. L., \& Sant'anna, A.S. (2017). Developing global transformational leaders. Journal of World Business. 52, pp. 461-473. http://dx.doi.org./10.1016/j.jwb.2016.06.002

Rana, F. (2014, December). Jack Ma, The Capitalist. TIME, Retrieved June 1 1 2020 from time.com > time-person-of-the-year-runner-up-jack-ma

Robbins, S. P., \& Judge, T. (2012). Essentials of organizational behaviour. Saddle Rivers: N.J. Pearson Higher Ed.

Robbins, S.P., Coulter, M., \& De Cenzo (2017) Management. 9th Edition, Prentice-Hall, London, UK.

Sen, A. \& Eren, E. (2012). Innovative leadership for the twenty-first century. Procedia-Social and Behavioral Sciences. 41. pp. 1-14.

Silva, A. (2014). What can we learn from great business leaders? Journal of Leadership Studies, Vol. 8. No, 3, pp. 52-57.

Sirisetti, S. (2011). Quality leadership in the public sector: Strategies and challenges. The Journal of Commerce, 3(4), 45.

Smet, A.D., Lurie, M., St George, A.m, (2018). Leading agile transformation: The new capabilities leaders need to build 21 st-century organizations. McKinsey \& Company.

Sobocka-Szczapa, H. (2019). Competence of a leader - a manager in an organization. Advances in Social Science, Education and Humanities Research, Vol. 318. 3rd International Conference on Social, Economic, and Academic Leadership (ICSEAL 2019), Atlantic Press.

Sosik, J. J., Jung, D.I, Berson, Y, Dionne, S, \& Jaussi, K. S. (2005). The strategic leadership of top executives in high-tech organizations. Organizational Dynamics, Vol. 34, No. 1, pp. 47-61.

Spears, L. C., \& Lawrence, M. (Eds.). (2002). Focus on Leadership: Servant Leadership for the twentyfirst century. New York, NY: John Wiley \& Sons.

Spicker, P. (2012). Leadership: a perniciously vague concept. International Journal of Public Sector Management, Vol. 25, No.1: pp. 34-47.

Tham, J. E., \& Yazdanifard, R. (2015. The review of Alibaba's operation management details that have navigated them to success. Global Journals of Management and Business Research (A) Vol, XV, Issue IV Version 1.

Toma, S. G. (2013. Steve Jobs and modern leadership. Change and Leadership. No, 17. pp. 260-269.

Toor, S-Ur-R., \& Ofori, G. (2008). Leadership versus management: How they are different, and why. Leadership and Management in Engineering, April, 28, https://www.ResearchGate. net/publication/ 245492919.

Toor, S-Ur-R. (2011). Differentiating leadership from management: An empirical investigation of leaders and managers. Leadership and Management in Engineering, 11(4): 330-320.

Tran, K.S. (2021). Leadership Capability: "What We Do as a Leader" International Journal of Innovation, Management and Technology, Vol. 12, No. 1, February 2021. doi:10.18178/ijimt.2021.12.1.900

Van Wart, M. (2013). Lessons from leadership theory and the contemporary challenges of leaders. Public Administration Review, 73 (4), 553-565.

Zaleznik, A. (1977). Managers and leaders. Harvard Business Review, 55, 67-78.

Zentner, A. (2016). Bill Gates: A Servant Leader. Retrieved May 11th, 2020 from SSRN: https://ssrn.com/abstract $=2761090$

Zeti: New generation of leadership needed. (2014, October 2nd). The Star, Starbiz pp. 4. 